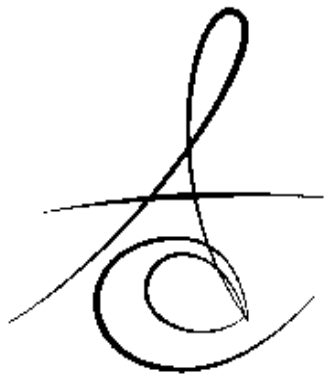

Makale Kodu/Article code: 2870

Makale Gönderilme tarihi: 31.05.2016

Kabul Tarihi: 30.09 .2016

\section{DİYABETLİ HASTALARDA ORTODONTİK TEDAVİ}

\section{ORTHODONTIC TREATMENT IN PATIENTS WITH DIABETES MELLITUS}

\author{
Dr. Öğr. Üyesi ÖZGE USLU AKÇAM *
}

öz

Diabetes mellitus, pankreastaki beta hücrelerinin yetersiz fonksiyonu sonucu insülin salgısındaki bozukluk nedeniyle meydana gelen kronik metabolik bir hastalıktır. Tip 1 diyabet (insuline bağımlı diyabet) ve Tip 2 diyabet (insuline bağımlı olmayan diyabet) olmak üzere 2 ana tipi bulunmaktadır. Periodontal hastalıklar, ağız kuruluğu (kserostomia), çürük insidansında artış, iyileşme zamanında uzama diyabetin ağız içi bulgularındandır. Bu hastalarda, dikkatli bir medikal anamnez alınmalı, randevular uygun saatlerde olmalı, kontrollü kuvvet uygulanmalı ve iyi bir ağız hijyeni sağlanmalıdır. Bu derlemenin amacı diabetes mellitusu tanımlamak; sınıflaması, etiyolojisi, oral belirtileri, komplikasyonları ve diyabetli hastalarda ortodontik yaklaşım hakkında bilgi vermektir.

Anahtar Kelimeler: Diyabet, ortodonti, tip 1 diyabet, tip 2 diyabet.

\section{GİRİS}

Diabetes mellitus, pankreastaki beta hücrelerinin yetersiz fonksiyonu sonucu insülin salgısındaki bozukluk nedeniyle meydana gelen kronik metabolik bir hastalıktır. Toplumların \%2-10'unu etkilemektedir, tüm dünyada ise yaklaşık ikiyüz milyon diyabetli hasta olduğu bildirilmiştir. ${ }^{1-3}$ Tüm dünya nüfusunun $\% 6^{\prime}$ sında diyabet hastalığı görüldüğü ve bu oranda zamanla artış olduğu rapor edilmiştir. ${ }^{4}$ TURDEP (The Turkish Diabetes Epidemiology Study) tarafından yapılan çalışmada ülkemizde 4.9 milyon diyabetli hasta olduğu, tip 2 diyabet prevalansının \%7.2 olduğu, bildirilmiştir. $^{5}$

\section{ABSTRACT}

Diabetes mellitus is a chronic metabolic disease caused by a defect in insulin secretion due to insufficient function of the beta cells in the pancreas. There are two main types of diabetes including Type 1 diabetes (insulin-dependent diabetes) and Type 2 diabetes (non-insulin dependent diabetes). Oral findings of the diabetes are periodontal diseases, xerostomia, increased caries incidence and prolonged wound healing. A careful medical history should be taken, appointments must be at convenient times, controlled force should be implemented and a good oral hygiene should be provided in these patients. The aim of this review is to define diabetes mellitus; provide information about classification, etiology, oral symptoms, complications and orthodontic approach in diabetic patients.

Keywords: Diabetes, orthodontics, type 1 diabetes mellitus, type 2 diabetes mellitus.

Diyabet, kandaki glukoz seviyesinin inatçı artışı ile oluşan ve insülin salınımında, aktivasyonunda veya ikisini birden içeren yetersizlik tablosu ile gelişen endokrin bir rahatsızlıktır. ${ }^{6}$

Diyabet sınıflaması insüline bağımlı olup olmamasına, klinik belirtilere ve tedavi gereksinimlerine göre yapılmaktadır. Buna göre Tip 1 Diyabet (Jüvenil tip, insuline bağımlı diyabet) Tip 2 Diyabet (Erişkin tip, insuline bağımlı olmayan diyabet) olmak üzere 2 ana tipi bulunmaktadır.

Diyabetin etiyolojiye dayalı sınıflandırması ise şu şekildedir: ${ }^{8}$

1. Tip 1 Diyabet $^{8}$

a. İmmun aracilı

b. İdiopatik

* Ankara Yıldırım Beyazıt Üniversitesi Diş Hekimliği Fakültesi, Ortodonti Anabilim Dalı, Ankara 


\section{Tip 2 Diyabet $^{8}$}

3. Diğer spesifik tipler ${ }^{8}$
a. Beta hücre fonksiyon defektleri
b. Ekzokrin pankreas hastalıkları
c. Endokrinopatiler
d. Enfeksiyonlar
e. İnsülin fonksiyon defektleri
f. İlaç/Kimyasal madde kaynaklı
g. İmmun sistem aracilı diyabet
h. Genetik sendromlarla ilişkili diyabet
I. Hamilelikle ilişkili diyabet

Tip 1 Diyabet: Tip 1 diyabet, insülin salınımındaki yetersizlik sonucu oluşmakta ve birey ömür boyu dışarıdan insülin almaya mecbur kalmaktadır. Çocuklarda ve genç erişkinlerde görüldüğü için 'jüvenil diyabet' adını da almaktadır. Erkeklerde ve kızlarda görülme sıklığı hemen hemen aynıdır. Çoğunlukla ergenlik döneminde teşhisi mümkün olmaktadır. 10-14 yaşlar arası artış yaptığı dönemdir. ${ }^{9-11}$ Hastalık belirtileri aniden başlamaktadır. Polidipsi, poliüri ve kilo kaybı gibi diyabete ait belirtiler şiddetlidir. Hipoglisemi, ketoasidoz koması gibi komplikasyonlar sık görülür. Yorgunluk, kas krampları, görmede bulanıklık, menstruasyon bozukluğu da görülebilmektedir. Davis ve ark. ${ }^{12}$, Tip 1 diyabetli çocukların \%8,5 'inin ciddi hipoglisemik koma, \%26.92'unun başka birinin yardımını isteyecekleri durumlar olduğunu tespit etmiştir.

Tip 2 Diyabet: En sık rastlanan diyabet tipidir. İnsülin aktivitesine direnç, insülin cevabında yetersizlik sonucu ortaya çıkar. Genellikle 40 yaştan sonra ortaya çıkar, erişkinlerde görülen diyabet tipidir ancak genetik yönü vardır. ${ }^{8}$ Obezite, insülin direnci ve insülin sekresyon bozukluğu ile karakterizedir. Beslenme düzeni kontrolü ve oral antidiabetik ilaçlarla kan şeker seviyeleri kontrol altında tutulmaktadır. Hastalığın klinik belirtileri poliüri, polifaji, polidipsi, yara iyileşmesinde gecikme, el ve ayaklarda uyuşma, halsizlik ve görme bozukluğudur. ${ }^{13}$

Toplumun \%3-10'unun Tip 1 diyabete sahip olduğu belirtilmiş; ırk ve ülke farklılıklarının önemli olduğu vurgulanmıştır. Tip 2 diyabet ise dünyada \%57 oranında tespit edilmiş olmasına rağmen teşhis edilmemiş vakaların oranının fazla olduğu düşünülmektedir. ${ }^{14}$ Türk toplumunda diyabet sıklığı $\% 7.2$ olarak belirtilmiştir. ${ }^{15,16}$

Gestasyonel Diyabet: Hamilelik esnasında ortaya çıkar, gebeliğe bağıı insülin direnci gelişir. Genetik olarak yatkın olan kadınlarda gebelik hormonları insülin direncine neden olmaktadır. Genellikle belirti vermeyen bir durumdur. Doğum ile genellikle düzelir ancak sonraki gebeliklerde tekrar görülür.

Gestasyonel diyabet, çocuğun doğumu ile düzelirken; Tip 1 ve 2 diyabet kronik durumlardır.

\section{Diyabet Etiyolojisi}

Tip 1 diyabetin nedeni otoimmunite olarak bilinmektedir. Otoimmünitenin yanı sıra konjenital kızamıkçık, hepatit, kabakulak ve sitomegalovirüs gibi viral enfeksiyonların Tip 1 diyabet gelişimini tetiklediği bildirilmiştir. ${ }^{17}$

Tip 2 diyabette ise genetik ve obezite başta gelen etkenlerdir. Bunlara ek olarak hastalığın ortaya çıkmasında beslenme bozukluğu, yaşın ileri oluşu, durağan bir hayat şekli, tansiyon yüksekliği, kolesterol ve trigliserid yüksekliği, ard arda olan gebelikler, gebelikte diyabet belirlenmesi gibi nedenler de önemlidir. Tip 2 diyabet, insülin direnci, bozulmuş insülin sekresyonu ve artmış karaciğer glikoz üretimi ile ilişkilidir. ${ }^{18}$ İnsülin direnci ve diyabet intimali vücut yağ miktarı arttıkça artmaktadır. Tip 2 diyabet gelişen genç hastaların çoğunun obez olduğu gözlenmektedir. ${ }^{19}$

Gestasyonel diyabetin etiyolojisinde ise gebeliğe bağlı insülin direnci ve genetik yatkınlık vardır. Gebe kadınların düşük riskini artırması açısından önemlidir. ${ }^{20}$

\section{Diyabetin Oral Belirtileri}

En sık rastlanan intra-oral bulgu; periodontal hastalıklardır. Kontrol altına alınmamış diyabetlilerde ağız kuruluğu, ağrılı glossit, periodontal apse, stomatit gibi şikâyetler de olabilmektedir. ${ }^{21}$ Kontrol altında olan diyabetlilerde de periodontal hastalıklar görülebilmektedir.

Cianciola ve ark. ${ }^{22}$, diyabetli ve diyabeti olmayan çocuklarda yapmış oldukları çalışmada periodontitis prevalansını Tip 1 diyabetlilerde \%9.8, diyabeti olmayanlarda $\% 1.7$ olarak belirlemişlerdir. Periodontitis prevalansının yaşla arttığı belirtilmiştir.

Rylander ve ark. ${ }^{23}$, insülinle kontrol altında olan genç diyabet vakalarını ve sağıklı genç bireyleri değerlendirmişlerdir. Retinopati ve nefropati görülen genç diyabetlilerde, komplikasyon görülmeyen diyabetlilere göre daha fazla gingival enflamasyon görülmüştür.

Tozoğlu ve Bilge ${ }^{24}$, diyabetik hastaların ağız kuruluğu, diş eti hastalıkları ve diş çürükleri açısından yüksek riske sahip olduklarını bildirmiştir. Bu

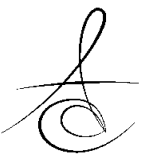


sebeplerle özellikle Tip 2 diyabetli hastalar ağız ve diş sağlığı için koruyucu uygulamalara gerek duyarlar.

\section{Diyabetin Komplikasyonları}

Sistemik komplikasyonlar: Diyabetin komplikasyonları akut ve kronik olarak ayrılır. Diyabetin akut komplikasyonları hipoglisemi, ketoasidoz, laktik asidoz ve bakteriyel/fungal enfeksiyonlardır. Diyabetin kronik komplikasyonları ise kardiyovasküler hastalıklar, retinopati, nefropati, nöropati, impotans ve ayak komplikasyonlarıdır.

Tip 1 ve tip 2 diyabet, karbonhidrat, lipit ve protein metabolizmalarındaki düzensizliklere ek kronik komplikasyonlara yol açar. ${ }^{25}$ Diyabet makrovasküler hastalık riskini önemli ölçüde arttırmaktadır. ${ }^{26}$

Diyabetik hastalarda böbrek yetmezliği, ekstremite ampütasyonları, felç, görme bozukluğu/ körlük ve miyokard enfarktüsü görülme riski fazladır.

Diyabetik hastalarda mikroanjiyopati ve ateroskleroz sonucunda vasküler komplikasyonlar gelişir, büyük damar duvarları kalınlaşır, damarlarda lipit birikimi ve ateroma formasyonu olur. Bu değişiklikler bütün vücutta oluşur ve diyabete bağlı komplikasyonların büyük çoğunluğundan sorumludur. ${ }^{27}$

Oral Komplikasyonlar: Hipergliseminin uygun kontrol edildiği vakalarda oral komplikasyonların çok az olacağı veya hiç görülmeyeceği klinik araştırmalarda gösterilmiştir . ${ }^{28,29}$ Kontrolsüz diyabet hatsalarında ağız kuruluğu, tükürük bezinde büyüme, tükürük akışında azalma, enfeksiyon eğiliminde artış, yara iyileşmesinde gecikme, kandidiazis, ağızda yanma hissi ve periodontal hastalık şeklinde oral komplikasyonlar gözlenmektedir. ${ }^{25}$ Tükürük akışında azalma sonucunda ağız kuruluğu görülmekte, çürük gelişimini ve kandidiazis oluşumunu da kolaylaştırmaktadır. ${ }^{25}$ Aksini iddia eden çalışmalar da mevcuttur. ${ }^{29}$ Kontrolsüz diyabet hastalarında tükürükteki artmış glikoz seviyeleri yüzünden çürük oluşumu artabilirken; kontrol altındaki diyabet hastalarında daha düşük karbonhidratlı diyetle beslenme çürük oluşumunu azaltabilir. ${ }^{29}$

Canepari ve ark. ${ }^{30}$, aynı diyetle beslenen diyabetli ve diyabeti olmayan çocuklarda çürük insidansını araştırdıkları çalışmalarında diş çürüğünün diyabetli çocuklarda daha yaygın görüldüğünü belirtmiştir. Diyabetli hastalarda diş çürükleri daha çok bukkal ve labial servikal alanlarda lokalizedir. ${ }^{31}$ Siudikiene ve ark. ${ }^{32}$, yaş arttıkça içecek ve atıştırmalık gıdaların daha sık tüketilmesi nedeniyle çocuklarda diş çürüğü gelişiminin etkilendiğini belirtmişlerdir.

\section{Diyabet Tedavisi}

Diyabet tedavisinde amaç kan glikoz seviyesini kontrol altına alarak hastanın normal sağlığına kavuşturulmasıdır. Tip 1 diyabet tedavisi çocuk ve ailesinin diyabetle ilgili bilgilendirilmesi, diyabeti kontrol altına almak için uygun diyet kullanımı ve insülin enjeksiyonu ile sağlanır. ${ }^{33}$ Çocuklarda, günlük fiziksel aktivite oranındaki değişiklik ve insülin ile diyet arasındaki dengeyi sağlamak zordur. Ayrıca, büyüme ve gelişmenin çocukluk döneminde farklı oranlarda olmasının da diyabetin kontrolünü güçleştirdiği tespit edilmiştir. Düzenli egzersiz yapılmasının da olumlu sonuç verdiği düşünülmektedir.

Tip 2 diyabet tedavisi ise diyetle ve oral hipoglisemik ajanlar ile sağlanır.

\section{Diyabetli Hastalarda Ortodontik}

\section{Yaklaşım:}

* İyi bir oral hijyen eğitimi verilmelidir.

* Kontrol altında olmayan diyabetiklerde yüksek periodontal yıkım ihtimali nedeniyle ortodontik tedaviden kaçınmak gerekir. Kontrol altında olan diyabet hastalarında ortodontik tedavi kontrendike değildir. ${ }^{34}$

* Kontrol altındaki diyabetiklerde nötrofil fonksiyonlarına bağlı olarak gingival enflamasyon görülebilir. Ortodontik tedavi süresince periodontal dokular değerlendirilmelidir.

* Diyabetli hastalarda sabah randevuları tercih edilebilir. Hastalara tok bir şekilde tedaviye gelmeleri, insülin veya oral antidiyabetik ilaçlarını almaları hatırlatılmalıdır. ${ }^{8,35}$

* Ortodontik açıdan hareketli ya da sabit apareyler arasında tedavi yönünden önemli bir fark yoktur. Tükürük akışının azalması ve damar değişimlerine bağlı olarak periodontal hastalık riski artacağından oral hijyen ölçümleri gerekmektedir. ${ }^{13,36,37}$ Sabit apareylerde plak retansiyonu daha fazla olduğu için diş çürüklerine ve dişeti problemlerine neden olabilmektedir. Bu nedenle özellikle sabit aparey kullanan hastalarda iyi bir oral hijyen sağlanmalı, günlük florlu gargara kullanımı önerilmelidir. ${ }^{38,39}$

* Diyabetik hastalarda hafif kuvvetlerle ortodontik tedavi önerilmektedir. ${ }^{37}$ Ortodontik diş hareketi sonucu periodontal yıkımın arttığı belirtilmiştir. ${ }^{40} \mathrm{Bu}$ nedenle tedavi öncesi, tedavi sırasında ve sonrasında periapikal radyografiler alınarak periodontal değerlendirme önerilmektedir.

* Periapikal vaskuler değişime bağlı olarak diş ağrısı, pulpitis, perküsyon hassasiyeti, diş dokularının 
canlılığını yitirmesi görülebilmektedir. Özellikle uzun süreli ortodontik kuvvet uygulanan dişlerde periyodik olarak diş dokularının canlılığ kontrol edilmelidir.

* Plak eliminasyonu için normal fırça ve ara yüz fırçası kullanımı, klorheksidinli gargaralar ve plak kontrolü tavsiye edilmektedir.

* Diyabetli hastalarda periodontal hastalık sıklığı ve şiddetinde artış olduğu bildirilmiştir. ${ }^{41-44}$ Periodontal hastalık, diyabetin en sık görülen komplikasyonlarından biri olarak kabul edilmektedir. ${ }^{36}$ Diyabetin immunolojik özelliklerinden dolayı gelişen iltihabi yanıtta artış, infeksiyonlara yatkınlık ve kollajen yapım-yıkım hızında azalma periodontal hastalığa yatkınlığa neden olmaktadır. ${ }^{36,45}$

* Diyabetik hastalar, kontrol grubuyla karşılaştırıldığında iskeletsel gelişimleri daha geride bulunmuş; boyutsal ve açısal sefalometrik ölçümleri daha düşük bulunmuştur. Kraniyofasiyal morfolojinin ve iskeletsel gelişimin özellikle pubertal gelişim atılımı öncesinde ve sırasında diyabetten etkilendiği belirtilmiştir. ${ }^{46} \mathrm{Bu}$ konu, ortodontik tedavi planında mutlaka göz önünde bulundurulmalıdır.

* Ortodontistler, her iki tip diyabet hastasıyla da karşılaşırlar. Tip 2 diyabet hastalarının, Tip 1 diyabet hastalarından daha stabil olduğu düşünülsede ${ }^{12}$; uygulanan diyetten ve insülin kullanımından sapmalar olduğu zaman serum glikoz seviyelerinde ani değişiklikler ve hipoglisemik reaksiyonlar görülebilmektedir. ${ }^{47}$

* Diş hekimi tedavisi sırasında gelişebilecek hipoglisemik şok açısından dikkatli olmalıdır. Hipogliseminin şiddeti hafif, orta ve ağır olabilir. Belirtileri açık, terleme, solukluk, çarpıntı, huzursuzluk, bulanık görme, taşikardi ve ağır tablolarda bilinç kaybı şeklinde olabilir. Hastaya yüksek karbonhidratlı bir içecek içirilebilir, orta derecede hipoglisemiye giren bireylerde birkaç adet kesme şeker verilebilir. Bir süre beklendikten sonra belirtiler azalarak hasta düzelir. Eğer bilinç kaybı varsa acil tıbbi yardım ile havayolu açık tutulmalı, oksijen desteği verilmeli ve yaşam belirtilerine dikkat edilmelidir. ${ }^{8}$

\section{SONUÇ}

Diyabetik çocuk ve yetişkin tüm hastaların diş tedavileri çok büyük önem taşımaktadır. Ortodontik tedavi, diğer diş hekimliği uygulamalarından daha az riskli görünse de tedavi planında ve özelliklede sabit ortodontik uygulamalarda dikkat edilmelidir. Diyabetli hastalarda; dikkatli bir tıbbi anamnez alınmalı, gerekli görülürse hastanın tıbbi doktoru ile görüş alışverişi yapılmalı, randevular uygun saatlere ayarlanmalı, kontrollü kuvvet uygulanmalı ve ağız bakımı ideal olarak sağlanmalıdır.

Özge Uslu Akçam: ORCID ID: 0000-0002-4885-3657

\section{KAYNAKLAR}

1. Rylander $H$, Ramberg $P$, Blohme $G$, Lindhe J. Prevalence of periodonal disease in young diabetics. J Clin Periodontol 1986;14:38-43.

2. Fıratlı E, Ünal T, Saka N, Onan U, Sivas A, Öz H. Serum fructosamine correlates with gingival index in children with insulindependent diabetes mellitus (IDDM). J Clin Periodontol 1994;21:5658.

3. Fıratlı E. Diabetes mellitus ve periodontal hastalıklar. İstanbul Diş Hekimleri Odası Dergisi 1998;63:40-1.

4. Al Shamsi M, Amin A, Adeghate E. Effect of vitamin $C$ on liver and kidney functions in normal and diabetic rats. Annals New York Academy of Sciences 2006;1084:371-90

5. Satman I, Yilmaz MT, and TURDEP group. Population-Based Study of Diabetes and Risk Characteristics in Turkey: Results of the Turkish Diabetes Epidemiology Study (TURDEP). Diabetes Care 2002;25:1551-6

6. Tuncer BB. Medikal sorunlu bireylerde ortodontik yaklaşımlar. Atatürk Üniv Diş Hek Fak Derg 2005;15:40-51.

7. Little RR, England JD, Weidmeyer HM, McKenzie EM, Pettitt DJ, Knowler WC, Goldstein DE. Relationship of glycosylated hemoglobin to oral glucose toleranse. Implications for diabetes screening. Diabetes 1988;37:60-4.

8. Bensch L, Braem M, Willems G. Orthodontic considerations in the diabetic patient. Semin Orthod 2004;10:252-8.

9. Dokheel TM. An epidemic of childhood diabetes in the United States? Evidence from Allegheny County, Pennsylvania. Pittsburgh Diabetes Epidemiology Research Group. Diabetes Care 1993;16:1606-11.

10. Meyle J, Gonzales JR. Influences of systemic diseases on periodontitis in children and adolescents. Periodontol 2000 2001;26:92-112. 
11. Burden M. Diabetes-associated cardiovascular risk factors. Nurs Stand. 2001;15:45-52.

12. Davis SN, Shavers C, Mosqueda-Garcia R, Costa F. Effects of differing antecedent hypoglycemia on subsequent counterregulation in normal humans. Diabetes 1997;46:1328-35.

13. Bensch L, Braem M, Van Acker K, Willems G. Orthodontic treatment considerations in patients with diabetes mellitus. Am J Orthod Dentofacial Orthop 2003;123:74-8.

14. Finney LS, Finney MO, Gonzalez-Campoy JM. What the mouth has to say about diabetes.Diabetes 1997;102:117-26.

15. Gokcel A, Baltali M, Tarim E, Bagis T, Gumurdulu Y, Karakose H, Yalcin F, Guvener N. Detection of Insulin Resistance in Turkish Adults: A Hospital Based Study. Diabetes Obesity \& Metabolism 2003;5:126-30.

16. Erem C, Yıldız R, Kavgacı H, Karahan C, Değer O, Can G, Telatar M. Prevalance of diabetes, obesity and hypertension in a Turkish population (Trabzon city). Diabetes Res Clin Pract 2001;54:203-8.

17. Krolewski AS, Warram JH, Rand LI, Kahn CR. Epidemiologic approach to the etiology of type 1 diabetes mellitus and its complications. N Engl J Med 1987;26:317:1390-8.

18. Altuntaş $Y$. Diabetes mellitusun tanımı, tanısı ve sınıflaması, Her yönüyle Diabetes Mellitus kitabı. Nobel Tıp Kitabevleri; İstanbul, 2001. p. 85-128.

19. Golay A, Felber JP, Jequier E, et al. Metabolic basis of obesity and non-insulin dependent diabetes mellitus. Diab Metab Rev 1988;4:727-47.

20. Coustan D. Gestational diabetes. Diabetes Care 1993;16:8-15.

21. Akan S, Kocadereli İ. Sistemik hastalıkların ortodontik tedaviye etkileri. Cumhuriyet Üniv Diş Hek Fak Derg 2008;11:66-74.

22. Cianciola LJ, Park BH, Bruck E, Mosovich L, Genco RJ. Prevalnace of periodontal disease in insülindependent diabetes mellitus (juvenile diabetes). J Am Dent Assoc 1982;10:653-60.

23. Rylander $H$, Ramberg $P$, Blohme $G$, Lindhe J. Prevalance of periodontal disease in young diabetics. J Clin Periodontol 1987; 14:38-43.
24. Tozoğlu Ü, Bilge OM. Tip 2 diyabetli hastalarda DMF indeksi, periodontal indeks, tükürük akışı ve tükürük PH'sının değerlendirilmesi. Atatürk Üniv Diş Hek Fak Derg 2009;19:145-50.

25. Tunalı M, Erşahan Ş, Aydınbelge M. Periodontal hastalık ile diyabet arasında çift yönlü ilişki. Sağlık Bilimleri Dergisi 2014;23:28-38.

26. Nathan DM. The pathophysiology of diabetic complications: how much does the glucose hypothesis explain? Ann Inter Med 1996;1:86-9.

27. Klein BE. Overview of epidemiologic studies of diabetic retinopathy. Ophthalmic Epidemiol 2007; 14:179-83.

28. Schmidt AM, Hori O, Cao R. RAGE, a novel cellular receptor for advenced glycosylation end products. Diabetes 1996;45:77-80.

29. Murrah VA. Diabetes mellitus and associated oral manifestations: A review. J Oral Pathol 1985;14:271-81.

30. Canepari P, Zerman N, Cavalleri G. Lack of correlation between salivary Streptococcus mutans and lactobacilli counts and caries in IDDM children. Minerva Stomatol. 1994;43:5015.

31. Ciglar L, Skaljac G, Sutalo J, Keros J, Jankovic B, Knezevic A. Influence of diet on dental caries in diabetics. Coll Antropol. 2002;26:311-7.

32. Siudikiene J, Maciulskiene V, Nedzelskiene I. Dietary and oral hygiene habits in children with type I diabetes mellitus related to dental caries. Stomatologija. 2005;7:58-62.

33. Özenen DÖ, Karataş MÖ, Sandallı N. Tip I diabetli çocuklarda oral değişiklikler. Cumhuriyet Üniversitesi Diş Hekimliği Fakültesi Dergisi 2007; 10:58-63.

34. Patel A, Burden DJ, Sandler J. Medical disorders and orthodontics. J Orthod 2009;36:1-21.

35. Pithon MM, Ruellas CV, Ruellas AC. Orthodontic treatment of a patient with Type 1 diabetes mellitus. J Clin Orthod 2005;39:435-9.

36. Loe $\mathrm{H}$. Periodontal disease:the sixth complication of diabetes mellitus. Diabetes Care 1993;16:32934.

37. Tervonen $\mathrm{T}$, Oliver RC. Long term control of diabetes mellitus and periodontitis. J Clin Periodontol 1993;20:431-5. 
38. Barkvoll P, Rolla G, Svendson AK. Interaction between chlorhexidine digluconate and sodium lauryl sulfate in vivo. J Clin Periodontol 1989; 16:593-5.

39. Owens J, Addy M, Faulkner J,et al. A short term clinical study design to investigate the chemical plaque inhibitory properties of mouthrinses when used as adjuncts to toothpastes:applied to chlorhexidine. J Clin Periodontol 1997;24:732-7.

40. Holtgrave EA, Donath K. Periodontal reactions to orthodontic forces in the diabetic metabolic state. Fortschr Kieferorthop 1989;50:326-37.

41. Lalla E, Kaplan S, Chang SM, Roth GA, Celenti R, Hinckley K, Greenberg E, Papanaou PN. Periodontal infection profiles in type 1 diabetes. J Clin Periodontol 2006;33:855-62.

42. Lalla E, Cheng B, Lal S, Kaplan S, Softness B, Greenberg E, Goland RS, Lamster IB. Diabetes mellitus promotes periodontal destruction in children. J Clin Periodontol 2007;34:294-8.

43. Pinson M, Hoffman WH, Garnick JJ, Litaker MS. Periodontal disease and type I diabetes mellitus in children and adolescents. J Clin Periodontol 1995;22:118-23.

44. Sbordone L, Ramaglia L, Barone A, Ciaglia RN, Iacono VJ. Periodontal status and subgingival microbiota of insülin-dependent juvenile diabetics: a 3 year longitudinal study. J Periodontal 1998;69:120-8.

45. Mealey BL, Oates TW. Diabetes mellitus and periodontal diseases. J Periodontal 2006;77:1289-303.

46. El-Bialy T, Aboul-Azm SF, El-Sakhawy M. Study of craniofacial morphology and skeletal maturation in juvenile diabetics (Type 1). Am J Orthpd Dentofacial Orthop 2000;118:189-95.

47. van Venrooy JR, Proffit WR. Orthodontic care for compromised patients: possibilities and limitations. J Am Dent Assoc 1985;111:262-6.

\section{Yazışma Adresi}

Dr. Öğr. Üyesi Özge Uslu Akçam

Ankara Yıldırım Beyazıt Üniversitesi

Diş Hekimliği Fakültesi Ortodonti

Anabilim Dalı.

Ayvalı mah, 150.sokak, Etlik-ANKARA

Tel: 03129062000

Faks: +90 3129062983

e-posta: ozgeusluakcam@gmail.com 